\title{
Kinerja Pemasaran Berbassis Orientasi Pasar serta Inovasi Produk pada Industri Mikro, Kecil dan Menengah Makanan Ringan Kabupaten Subang
}

\author{
Dwi Gemina \\ Universitas Djuanda Bogor \\ Endang Silaningsih \\ Universitas Djuanda Bogor \\ Karimatun Nisa \\ Universitas Djuanda Bogor \\ Email: dwigemina@gmail.com
}

\begin{abstract}
Abstrak
Industri Mikro Kecil Menengah (IMKM) memberikan sumbangan berarti bagi pertumbuhan ekonomi nasional, sebagai penggerak pembangunan daerah dibidang teknologi, memperluas kesempatan berusaha, kesempatan kerja dan peningkatan nilai tambah. Tujuan dari penelitian ini tanggapan pemilik usaha terhadap orientasi pasar, inovasi produk dan kinerja pemasaran IMKM makanan ringan di Kabupaten Subang serta untuk menganalisis kinerja pemasaran dipengaruhi secara simultan dan parsial oleh orientasi pasar dan inovasi produk pada IMKM makanan ringan di Kabupaten Subang. Metode penelitian adalah deskriptif dan verifikatif dengan skala likert menggunakan pengujian regresi berganda, sampel berjumlah 50 IMKM makanan ringan menggunakan metode purposive sampling, kemudian kuesioner diuji validitas dan reliabilitas Hasil dari pengujian tersebut data dinyatakan valid dan reliabel serta melakukan uji asumsi klasik untuk regresi berganda. Hasil penelitian bahwa secara simultan dan parsial variabel orientasi pasar dan inovasi produk berpengaruh positif dan signifikan terhadap kinerja pemasaran IMKM makanan ringan di Kabupaten Subang.
\end{abstract}

Kata Kunci: Orientasi Pasar, Inovasi Produk, Kinerja Pemasaran

\section{Pendahuluan}

Usaha Mikro Kecil dan Menengah atau Industri Mikro, Kecil dan Menengah (UMKM atau IMKM) merupakan sektor yang cukup penting dalam memerankan berbagai kepentingan ekonomi dalam pembangunan nasional, terutama bagi penciptaan usaha dan lapangan pekerjaan baru. UMKM atau IMKM sebagai basis ekonomi rakyat memiliki dampak langsung dalam memperkuat fundamental ekonomi, karena sebagian besar aktivitas ekonomi rakyat Indonesia lebih banyak diperankan dalam unit-unit ekonomi dalam skala UMKM atau IMKM hampir di semua sektor (Tanjung, 2017).

Kontribusi strategis sektor UMKM atau IMKM membuat pemerintah terus mengembangkan pertumbuhan UMKM atau IMKM Indonesia agar terciptanya kemandirian ekonomi dan kesejahteraan masyarakat. Bentuk upaya pemerintah salah satunya dengan program one village, one product yang dirintis pada tahun 2007, bertujuan untuk membangun kemandirian dan kesejahteraan ekonomi lokal dengan mengandalkan khas dan kebudayaan lokal memiliki potensi. Produk kebanggaan lokal yang mendominasi program ini adalah kerajinan dan makanan (Zulkarnain, 2013). Industri pengolahan menjadi penggerak perekonomian, dan memiliki kemampuan untuk menghasilkan nilai tambah barang serta terciptanya lapangan kerja. IMKM makanan ringan termasuk kelompok industri yang cukup progresif perkembangannya di Indonesia.

Kriteria IMKM menurut UU No 28 tahun 2008 dapat dilihat perbedaan antara industri kecil dan menengah pada jumlah aset dan omzet masing-masing. Industri kecil dengan aset $>$ Rp50juta-Rp500 juta dan omzet >Rp300 juta-Rp2,5 miliar serta industri menengah dengan 
jumlah aset>Rp500 juta-Rp10 miliar dan omzet sebesar>Rp2,5 miliar-Rp50 miliar (Saiman, L, 2013). Sedangkan kriteria menurut BPS, perbedaan industri kecil dan menengah dapat dilihat dari jumlah tenaga kerja. Untuk industri mikro jumlah tenaga kerja menurut BPS tahun 2014 adalah 4 orang, industri kecil dengan tenaga kerja 5-19 orang dan industri menengah dengan jumlah tenaga kerja 20-99 orang. Jika jumlah tenaga kerja > 99 orang, maka termasuk dalam kategori industri besar (Tambunan, T, 2012).

Kabupaten Subang berada di Provinsi Jawa Barat yang memiliki luas wilayah 205.176,95 ha atau 6,34 persen. Berdasarkan topografinya, wilayah Kabupaten Subang dapat dibagi kedalam tiga zona, yaitu pegunungan di Selatan, bukit dan dataran dibagian tengah dan dataran rendah dibagian utara. Ketiga zona tersebut memiliki sumber daya alam melimpah, jika dimanfaatkan secara optimal dapat meningkatkan taraf hidup penduduk. Salah satu potensi yang menjadi perhatian pemerintah adalah banyaknya usaha dan industri kecil tumbuh dan tersebar diwilayah Subang. Kontribusi IMKM terhadap Produk Domestik Regional Bruto (PDRB) atas dasar harga tanpa migas di Kabupaten Subang berikut ini:

Tabel 1. PDRB Atas Dasar Harga Berlaku di Kabupaten Subang Tahun 2015 - 2018

\begin{tabular}{lccc}
\hline Tahun & Jumlah (Rp) & Persentasi (\%) & Perubahan (\%) \\
\hline 2015 & 21.243 .243 & 21,5 & - \\
2016 & 23.227 .841 & 23,6 & 2,1 \\
2017 & 25.985 .952 & 26,4 & 2,8 \\
2018 & 28.106 .844 & 28,5 & 2,1 \\
\hline Total & 98.563 .880 & 100 & 7 \\
\hline Rata-rata & 24.640 .970 & 25 & 2,3 \\
\hline
\end{tabular}

Sumber: Badan Pusat Statistik Kabupaten Subang, 2019.

Rata-rata PDRB selama empat tahun sebesar Rp24.640.970 dengan presentasi 25 persen dan perubahan 2,3 persen. Masyarakat Kabupaten Subang pada umumnya memanfaatan hasil pertanian dan perkebunan menjadi berbagai bentuk olahan camilan, salah satunya dalam bentuk makanan ringan diantaranya aneka dodol, aneka keripik, opak, rengginang dan wajit. Selain itu sebagai daerah penghasil buah nanas terbesar di Jawa Barat, Kabupaten Subang mengembangkan buah nanas untuk dijadikan olahan makanan yang berbahan dasar nanas, seperti dodol nanas, keripik nanas dan berbagai aneka kue. Adapun klasifikasi data IMKM makanan ringan di Kabupaten Subang pada Tabel 2 berikut ini:

Tabel 2. Klasifikasi Data Industri Mikro, Kecil dan Menengah Makanan Ringan Kabupaten Subang Tahun 2018

\begin{tabular}{clc}
\hline No & \multicolumn{1}{c}{ Jenis Makanan } & Jumlah (Unit) \\
\hline 1 & Dodol Nanas, Dodol Susu, Dodol Nangka, Dodol Kawista & 52 \\
2 & Opak, Rengginang, Ambrug, Rempeyek & 179 \\
3 & Keripik Pisang, Keripik Singkong, Keripik Gitrek, Selai Pisang, & 233 \\
& Keripik Nangka, Keripik Nanas & 11 \\
4 & Wajit & 84 \\
5 & Kue (Kering/Basah), Bolu, Roti, Donat, Bakpau & 5 \\
6 & Moring & 12 \\
7 & Aneka Kacang & 25 \\
8 & Papais & $\mathbf{6 0 1}$ \\
\hline
\end{tabular}

Sumber: Dinas Koperasi, Perindustrian dan Perdagangan Kabupaten Subang, 2019 (Data diolah) 
Jumlah klasifikasi IMKM Kabupaten Subang sebesar 601 dengan delapan jenis makanan. Meningkatnya persaingan memperebutkan pasar menyebabkan setiap industri menetapkan strategi yang tepat dalam memasarkan produknya. Apabila industri tidak mampu bertahan dalam persaingan, maka mengalami kerugian dalam market sharenya (Ferdinand, 2002). Keterbatasan teknologi yang digunakan untuk proses produksi, lemahnya manajemen finansial, sumber daya manusia kurang trampil menjadi masalah dihadapi oleh para pemilik IMKM di Kabupaten Subang, selain itu jenis produk dihasilkan oleh IMKM makanan ringan relatif sama dan produsen yang membuat produk sejenis banyak, sehingga persaingan cukup ketat dengan kemampuan merespon pesaing masih lemah, distribusi produk belum merata, penjualannya dibeberapa titik saja. Permasalahan lain adalah produk yang dihasilkan homogen sehingga inovasi lemah, variasi dalam membuat produk masih rendah, menciptakan produk baik rasa maupun bentuk baru masih lemah, dilihat dari kemasan variasi bentuk serta rasa produk masih kurang menarik. Perlunya diperhatikan oleh setiap industri adalah membuat suatu strategi yang digunakan untuk meningkatkan kinerja pemasarannya. Strategi diterapkan dalam setiap industri direncanakan dan diarahkan untuk membangun keunggulan bersaing sehingga dapat memenangkan persaingan. Semua strategi yang dibuat diharapkan mampu meningkatkan kinerja pemasarannya (Permadi, 2000). Dari permasalahan yang ada pada IMKM makanan ringan di Kabupaten Subang. Melalui orientasi pasar dan inovasi produk dapat dijadikan sebagai strategi oleh pelaku usaha IMKM makanan ringan di Kabupaten Subang.

Orientasi pasar dan inovasi produk bagi IMKM makanan ringan di Kabupaten Subang akan memberikan kontribusi pada penerapan strategi pemasaran yang baik oleh pihak manajemen. Hal ini tentu akan berdampak pada tingkat keefektifitasan kinerja pemasaran pada pelaku industri. Kinerja pemasaran diukur atau dinilai dari data tingkat penjualan, peningkatan penjualan, jumlah pelanggan, atau data lain yang menggambarkan tingkat keberhasilan pemasaran produk atau jasa dari sebuah perusahaan (Mulyani, 2015). Akselerasi perubahan menuntut perusahaan untuk lebih memperhitungkan faktor-faktor eksternal disamping mempersiapkan faktor-faktor internal agar dapat bergerak proaktif dan memposisikan diri secara lebih efektif ditengah-tengah persaingan yang kompetitif. Adanya analisis yang cermat terhadap faktor eksternal merupakan orientasi pasar dan inovasi produk.

\section{Landasaran Teori dan Pengembangan Hipotesis}

\section{Orinetasi Pasar, Inovasi Produk dan Kinerja Pemasaran}

Menurut Uncles (2000) merupakan suatu proses dan aktivitas yang berkaitan dengan penciptaan dan pemuasan pelanggan melalui kebutuhan dan keinginan pelanggan. Orientasi pasar memiliki tiga komponen, menurut Tjiptono dan Chandra (2012) komponen orientasi pasar yaitu; 1) Orientasi pelanggan; 2) Orientasi pesaing; 3) Koordinasi antar fungsi. Menurut Suryana dan Bayu (2010) bahwa inovasi produk merupakan pengetahuan produk baru dan sering kali dikombinasikan dengan hal baru, membentuk metode produksi yang tidak diketahui. Menurut Machfoedz (2015) menyebutkan bahwa inovasi produk terdiri dari empat jenis yaitu, penemuan, pengembangan, duplikasi dan sintesis. Sedangkan indikator dari inovasi produk menurut Lukas dan Ferrel (2000) terdiri dari: 1) Perluasan lini; 2) Produk baru; 3) Produk benar-benar baru. Sedangkan menurut Tjiptono (2008) kinerja pemasaran merupakan titik overspent dan underdelivered, karena sulitnya mengukur efektifitas dan efisiensi setiap aktivitas, keputusan atau program pemasaran. Sehingga kinerja pemasaran lebih obyektif dan terfokus pada profitabilitas dan produktivitas keputusan pemasaran.

\section{Pengembangan Hipotesis}


Kinerja pemasaran menurut Ferdinand (2006) merupakan faktor yang umum digunakan mengukur dampak dari strategi yang diterapkan oleh setiap industri. Menghasilkan kinerja pemasaran dan peningkatan daya saing pada IMKM dilakukan dengan pemahaman kebutuhan pasar. Kebutuhan pasar atau orientasi pasar merupakan ukuran perilaku dan aktivitas mencerminkan implementasi pada konsep pemasaran (Tjiptono, 2008). Orientasi pasar merupakan proses dan aktivitas yang berhubungan dengan penciptaan dan pemuasan pelanggan yang terus menerus menilai kebutuhan dan keinginan pelanggan. Inovasi produk dijadikan sebagai salah satu strategi mencapai kinerja pemasaran. Inovasi menjadi semakin penting sebagai sarana bertahan menghadapi ketidakpastian lingkungan dan kondisi persaingan bisnis meningkat. Inovasi produk menciptakan berbagai desain produk, sehingga meningkatkan alternatif pilihan, manfaat atau nilai yang diterima oleh pelanggan, serta meningkatkan kualitas produk yang diharapkan (Prajogo \& Sohal, 2001).

Dalam penelitian yang dilakukan oleh Fahmi Sulus (2017) bahwa orientasi pasar dan inovasi produk berpengaruh positif dan signifikan terhadap kinerja pemasaran. Kebutuhan pasar atau orientasi pasar sebagai ukuran perilaku dan aktivitas yang tercermin pada implementasi konsep pemasaran, orientasi pasar sendiri berpotensi meningkatkan kinerja pemasaran. Berdasarkan penelitian yang telah dilakukan oleh Baker dan Sinkula (1999) bahwa orientasi pasar secara signifikan berpengaruh terhadap kinerja pemasaran. Penelitian terdahulu yang dilakukan oleh Nerver dan Slater (1990) serta Han (1998) membuktikan bahwa adanya hubungan positif antara inovasi dan kinerja pemasaran. Didukung penelitian yang dilakukan oleh Dwiyono (2006) bahwa semakin tinggi inovasi produk maka semakin tinggi pula kinerja pemasaran.

Dari hasil penelitian dan pendapat tersebut maka hipotesis sebagai berikut; 1) Terdapat pengaruh positif dan signifikan orientasi pasar dan inovasi produk terhadap kinerja pemasaran $\left(\mathrm{H}_{1}\right)$; 2) Terdapat pengaruh positif dan signifikan orientasi pasar terhadap kinerja pemasaran $\left(\mathrm{H}_{2}\right)$; 3) Terdapat pengaruh positif dan signifikan inovasi produk terhadap kinerja pemasaran $\left(\mathrm{H}_{3)}\right.$. Kerangka pemikiran dalam penelitian berikut ini:

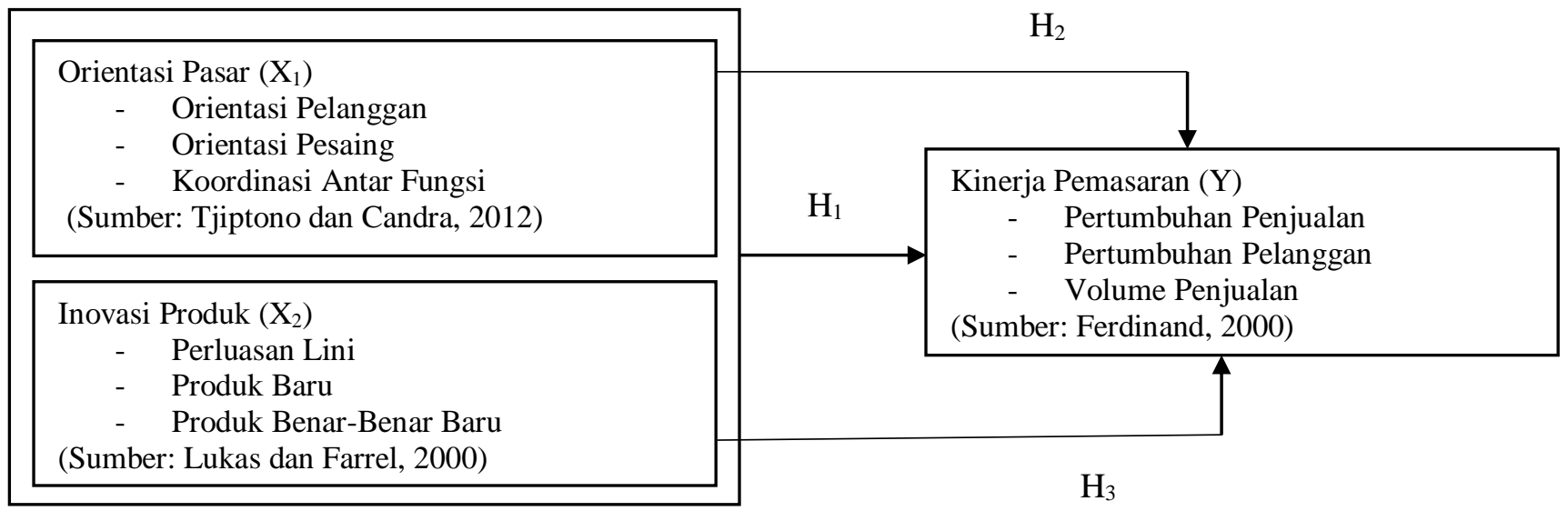

Gambar 1. Kerangka Pemikiran

\section{Metode Penelitian}

\section{Objek dan Lokasi Penelitian}

Objek penelitian ini adalah IMKM Makanan Ringan dan lokasi penelitian di Kabupaten Subang. Alasan dipilihnya objek penelitian ini karena Kabupaten Subang merupakan salah satu daerah di Jawa Barat, sehingga penduduk Kabupaten Subang mempunyai potensi yang cukup besar untuk berwirausaha dengan memanfaatkan sumber daya alam yang melimpah. 


\section{Desain Penelitian}

Desain penelitian digunakan adalah metode deskriptif dan verifikatif. Menurut Supardi (2013) penelitian yang menggambarkan apa yang dilakukan, berdasarkan faktor-faktor yang ada untuk selanjutnya diolah menjadi data dan kemudian dianalisis untuk memperoleh suatu kesimpulan yang berlaku untuk umum. Verifikatif adalah metode penelitian yang bertujuan digunakan untuk menguji kebenaran dari suatu hipotesis (Mashuri, 2008). Sedangkan operasionalisasi variabel berikut ini.

Tabel 3. OperasionalisasiVariabel

\begin{tabular}{|c|c|c|c|}
\hline Variabel & Konsep Variabel & Indikator & Skala Ukur \\
\hline $\begin{array}{l}\text { Orientasi Pasar } \\
\text { (Sumber: Tjiptono dan } \\
\text { Chandra, 2012) }\end{array}$ & $\begin{array}{l}\text { Ukuran perilaku dan } \\
\text { aktivitas yang tercermin } \\
\text { pada implementasi konsep } \\
\text { pemasaran }\end{array}$ & $\begin{array}{l}\text { 1. Orientasi pelanggan } \\
\text { 2. Orientasi pesaing } \\
\text { 3. Koordinasi antar fungsi }\end{array}$ & Ordinal, Likert \\
\hline $\begin{array}{l}\text { Inovasi Produk } \\
\text { (Sumber: Lukas dan } \\
\text { Ferrel, 2000) }\end{array}$ & $\begin{array}{l}\text { Suatu proses dalam } \\
\text { membawa teknologi } \\
\text { untuk digunakan } \\
\text { mengembangkan guna } \\
\text { tersebut }\end{array}$ & $\begin{array}{l}\text { 1. Perluasan lini } \\
\text { 2. Produk baru } \\
\text { 3. Produk benar-benar baru }\end{array}$ & Ordinal, Likert \\
\hline $\begin{array}{l}\text { Kinerja Pemasaran } \\
\text { (Sumber: Ferdinand, } \\
\text { 2000) }\end{array}$ & $\begin{array}{l}\text { Faktor yang digunakan } \\
\text { untuk mengukur dampak } \\
\text { dari strategi diterapkan } \\
\text { perusahaan }\end{array}$ & $\begin{array}{l}\text { 1.Pertumbuhan Penjualan } \\
\text { 2.Pertumbuhan pelanggan } \\
\text { 3. Volume penjualan }\end{array}$ & Ordinal, Likert \\
\hline
\end{tabular}

\section{Sampel Penelitian}

Jumlah populasi 601 unit usaha berdasarkan kriteria Dinas Koperasi, Perindustrian dan Perdagangan Kabupaten Subang, 2019 sebagai berikut: 1) Lama usaha lebih dari 1 tahun; 2) Usaha atau Industri tersebut tersebar di wilayah Kabupaten Subang; 3) Sebagian besar usaha tersebut merupakan usaha padat karya; 4) Penggunaan teknologi masih sederhana. Ada 500 unit usaha IMKM makanan ringan di Kabupaten Subang memenuhi kriteria tersebut. Menurut Arikunto (2011) ukuran yang layak dalam penelitian adalah antara 30 sampai dengan 500, sedangkan menurut Gay dan Diehl (1992) menyebutkan bahwa jika jenis penelitiannya adalah deskriptif maka sampel minimal adalah $10 \%$, untuk memenuhi syarat tersebut maka diambil sebesar 50 sampel. Adapun IMKM makanan ringan di Kabupaten Subang berikut ini.

Tabel 4. Daftar Industri Mikro, Kecil, dan Menengah Makanan Ringan Kabupaten Subang

\begin{tabular}{|c|c|c|c|c|}
\hline No & Nama Pemilik & Nama Perusahaan & Alamat & Jenis Makanan \\
\hline 1 & Ahmad Badri & Family Bakery & $\begin{array}{l}\text { J1. Palabuan No. } 60 \text { RT 11/02 Kel. } \\
\text { Sukamelang Kecamatan Subang }\end{array}$ & Roti Bakar \\
\hline 2 & Ade Wiwi & Mawar & $\begin{array}{l}\text { Kp. Sukajadi RT 24/08 Desa } \\
\text { Cijambe Kecamatan Cijambe }\end{array}$ & Opak \\
\hline 3 & Miseri & Ar-Rohmah & $\begin{array}{l}\text { Jl. Raya Cijambe Kecamatan } \\
\text { Cijambe }\end{array}$ & Kerupuk Jamur \\
\hline 4 & Aam Suhaemi & Restu & $\begin{array}{llll}\text { Cicadas } & \text { RT } & 08 / 02 & \text { Sagalaherang } \\
\text { Subang } & & & \end{array}$ & Keripik \\
\hline 5 & Isur Suryati & Mulqi Rasa & $\begin{array}{l}\text { Desa Cicadas RT 10/02 Kecamatan } \\
\text { Sagalaherang }\end{array}$ & $\begin{array}{l}\text { Sistik Bayam, } \\
\text { Keripik Pisang }\end{array}$ \\
\hline 6 & A Yani & Intan & $\begin{array}{l}\text { Jl. Raya Cicadas Desa Cicadas } \\
\text { Kecamatan Sagalaherang }\end{array}$ & $\begin{array}{l}\text { Keripik Singkong, } \\
\text { Keripik Pisang, } \\
\text { Sale Pisang }\end{array}$ \\
\hline
\end{tabular}


INOBIS: Jurnal Inovasi Bisnis dan Manajemen Indonesia Volume 02, Nomor 02, Maret 2019

Dwi Gemina, Endang Silaningsih, Karimatun Nisa

$7 \quad$ Iis Farida

Kharisma

\begin{tabular}{|c|c|c|}
\hline 8 & Ricky & Donat Bohay \\
\hline 9 & $\begin{array}{l}\text { Gumilar } \\
\text { Nurhayati }\end{array}$ & Selera Rakya \\
\hline 10 & Suhmi & Harapan Asih \\
\hline 11 & Amin Suprianto & Winda \\
\hline 12 & Arief Syaripudin & Mandiri Jaya \\
\hline 13 & Aneng & $\begin{array}{l}\text { Karpuk } \\
\text { Kadeudeumes }\end{array}$ \\
\hline 14 & Cartas & CSR Cinta Rasa \\
\hline
\end{tabular}

15 Cucu Erviani

16 Dedeh

\section{Nurjanah}

17 Susilawati

18 Enung

19 Rasudin

20 Tarsih

21 Juariah

22 Iah

23 Esa Maesaroh

24 Aan Yani

25 Hj. Oyok Tj

26

27 Wilma Tresnasari

28 Makmur

Siti Regina

Mandiri

Densus 2

Sausan

Asmanah Bunda

Katineung Rasa

Sinar Terang

Kacang Asin

Nini Iyom Opak

Karuhun

Akrab

Nolly

Motekar Jaya

Dunianti Bakery /

Delipel

29 Gani

Gumilar

$$
\text { Cahya Alfin }
$$

30 Haris Hidayat

Fazar

31 Idar Winarti

Sarikaya Bakery

Retno Sari
Kampung. Cicadas RT 09/02 Desa Cicadas Kecamatan Sagalaherang

J1. Cijambe Desa Cijambe Kecamatan Cijambe

Kampung Cisusuh RT 26/07 Desa.

Cijambe Kecamatan Cijambe

Desa Cijambe Cisusuh Kecamatan Cijambe

Kampung Sindanglaya RT 28/02

Kecamatan Tanjungsiang

Kampung Cileles RT 02/01 Desa

Sindanglaya Kecamatan Tanjugsiang

Desa Tambakmekar Kecamatan

Jalancagak

Kampung Sindangrasa RT 03/01

Desa Gadasoli Kecamatan

Tanjungsiang

Kampung Rancabogo RT 05/02 Desa

Tambakmekar Kecamatan

Jalancagak

Putri Kampung Tambakan RT 15/04 Desa

Tambakan Kecamatan Jalancagak

Kampung Cijambe RT 20/01

Kelurahan Cijambe Kecamatan

Cijambe

Jl. Lempar Ciranggeong Kelurahan

Cijambe Kecamatan Cijambe

Desa Tambakmekar Kecamatan

Jalancagak

J1. Raya Tambakan RT 15/03 Desa

Tambakan Kecamatan Jalancagak

Desa Tambakjati Tegal Koneng

Kecamatan Patokbesi

Desa Tambakjati Kecamatan

Patokbesi

Kampung Sukamenak Desa Cisalak

Kecamatan Cisalak

J1. Raya Cicadas Desa Cicadas

Kecamatan Sagalaherang

Kampung Sukamenak RT 22/07

Desa Pagaden Kecamatan Subang

Kampung Cilimus RT 11/03 Desa Papais Cisaat

Cisaat Kecamatan Ciater

Jl. Sompi Gang Janaka No. 6

Cigadug Subang

Jl. MT Haryono No. 39 RT 62/20 Roti, Donat

Cigadung Subang

Desa Rawalele Kecamatan Dawuan Roti

Kampung Panyongsongan RT 05/02

Desa Gandasoli Kecamatan

Tanjungsiang
Kampung Rancabogo RT 04/02 Desa

Tambakmekar Jalancagak
Keripik Singkong,

Keripik Pisang,

Sale Pisang

Donat

Rangining

Opak

Keripik Singkong

Keripik Pisang

Kerupuk

Kadeudeumes

Keripik Gelombang

Dodol Nanas

Sale Pisang, Sale

Gulung Unyil

Bakso dan Basreng

Kremes/Seroja

Dodol Nanas

Keripik Pisang,

Gitrek Tepung

Beras

Keripik Pisang,

Gipang

Kacang Asin

Opak

Kripik Singkong

Rempeyek

Aneka Kue Kering

Keripik Singkong

Dodol Nanas 
INOBIS: Jurnal Inovasi Bisnis dan Manajemen Indonesia Volume 02, Nomor 02, Maret 2019

\section{Dwi Gemina, Endang Silaningsih, Karimatun Nisa}

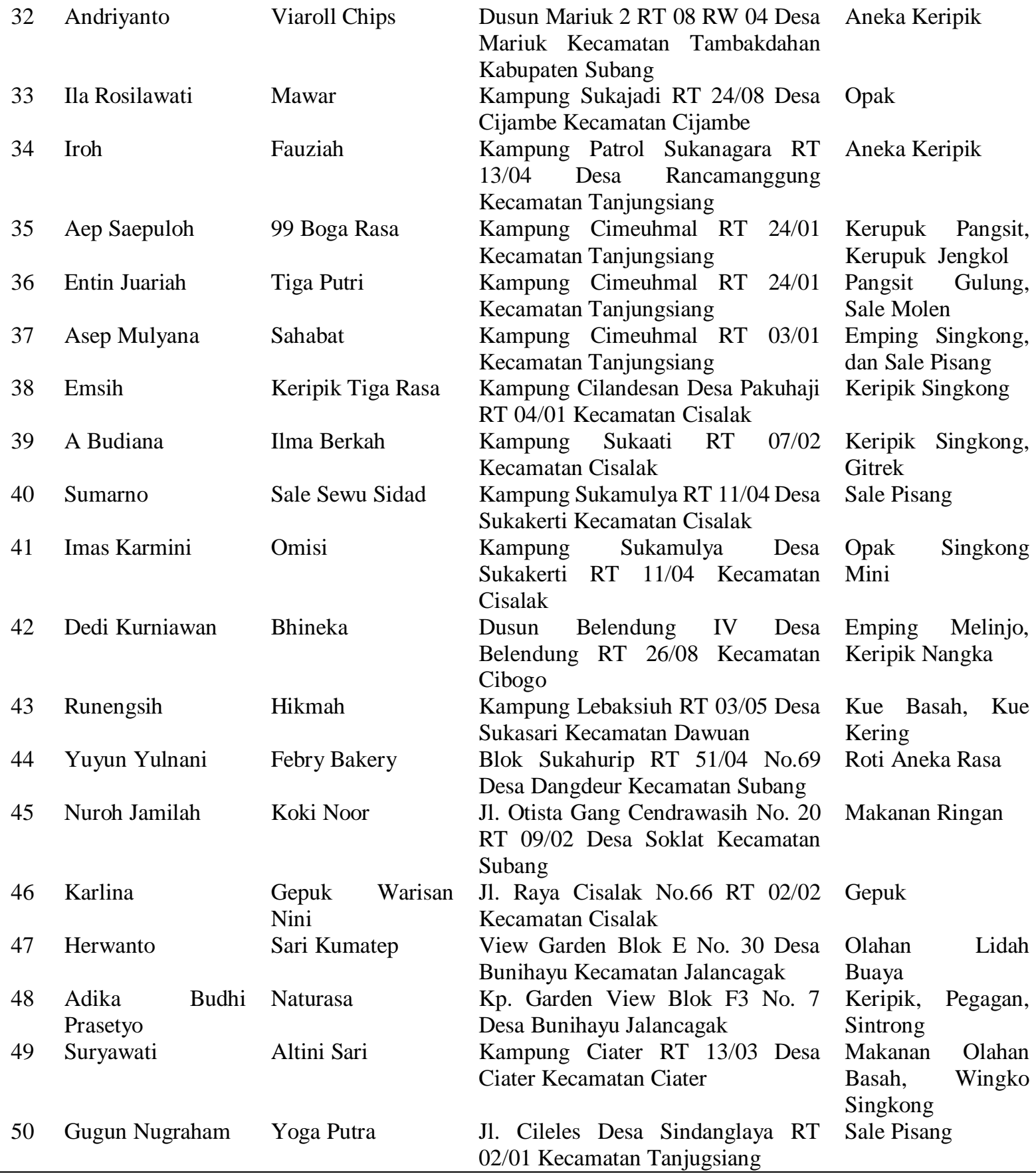

Sumber: Dinas Koperasi, Perindustrian dan Perdagangan Kabupaten Subang, 2019 (Data diolah)

\section{Metode Analisis Data}

Metode analisis datadigunakan uji statistik (Usman dan Akbar, 2006). Di mana sebelumnya diolah digunakan skala likert dari jenis kueioner tertutup pertanyaan yang diberikan kepada pemilik usaha dari satu sampai lima pada setiap butir kuesioner digunakan metode analisis data sebagai berikut:

a. Analisis regresi berganda, yang secara umum digunakan persamaan sebagai berikut: 
INOBIS: Jurnal Inovasi Bisnis dan Manajemen Indonesia Volume 02, Nomor 02, Maret 2019

Dwi Gemina, Endang Silaningsih, Karimatun Nisa

$$
\mathrm{Y}=\mathrm{a}+\beta_{1} \mathrm{X}_{1}+\beta_{2} \mathrm{X}_{2}+\varepsilon
$$

Dimana $\mathrm{Y}=$ Kinerja Pemasaran; $\mathrm{a}=$ Konstanta; $\mathrm{X}_{1}=$ Orienasi Pasar; $\mathrm{X}_{2}=$ Inovasi Produk; $\varepsilon=$ Faktor lain yang tidak diteliti

b. Analisis korelasi berganda, yang digunakan untuk mengetahui derajat atau hubungan orientasi pasar dan inovasi produk dengan kinerja pemasaran, serta untuk mengetahui kontribusi yang diberikan orientasi pasar dan inovasi produk terhadap kinerja pemasaran.

c. Analisis koefisien determinasidengan rumus sebagai berikut: $\mathrm{KD}=r^{2} \times 100 \%$ Di mana KD = Koefisien Determinasi dan $r=$ Koefisien korelasi

d. Pengujian hipotesis, secara simultan digunakan Uji-F sedangkan secara parsial digunakan Uji-t.

\section{Pembahasan}

\section{Karakteristik Pemilik Usaha}

Adapun rekapitulasi karakteristik pemilik usaha berikut ini:

Tabel 5. Rekapitulasi Karakteristik Pemilik Usaha

\begin{tabular}{lllll}
\hline No & Karakteristik & Ciri-ciri Pemilik Usaha & $\begin{array}{l}\text { Jumlah Pemilik Usaha } \\
\text { (Orang) }\end{array}$ & Presentasi (\%) \\
\hline 1 & Jenis Kelamin & Perempuan & 34 & 68 \\
2 & Usia & 44-55 Tahun & 20 & 40 \\
3 & Status Pernikahan & Menikah & 44 & 88 \\
4 & Pendidikan Terakhir & SMP/Sederajat & 24 & 48 \\
5 & Lama Usaha & >10 Tahun & 21 & 42 \\
6 & Pendapatan Perbulan & Rp10 Juta - Rp49 Juta & 24 & 48 \\
7 & Pendapatan/Omzet Pertahun & < Rp300 Juta & 37 & 74 \\
8 & Keuntungan Perbulan & <Rp9.900.000 & 31 & 62 \\
9 & Jumlah Kekayaan & <Rp50 Juta & 20 & 40 \\
10 & Jumlah Tenaga Kerja & <5 Orang & 32 & 64 \\
11 & Ijin Usaha & Memiliki Ijin Usaha & 43 & 86 \\
\hline
\end{tabular}

Sumber : Data diolah, 2019

Berdasarkan Tabel 5 dapat dilihat bahwa menunjukan sebagai perempuan yang bisa memanfaatkan keahliannya tanpa harus bekerja diluar rumah dan menjalankan usaha atau bisnisnya berusia produktif karena menurut UU No.13 tahun 2013 tentang Ketenagakerjaan dikatakan bahwa usia produktif yaitu 15-65 tahun. Sudah menikah sehingga memiliki rasa tanggung jawab yang lebih terhadap usaha atau IMKM yang ditekuni serta dapat memperoleh penghasilan tambahan untuk memenuhi kebutuhan keluarganya. Bahwa untuk berwirausaha tidak harus memiliki tingkat pendidikan yang tinggi melainkan memiliki jiwa wirausaha. Usaha IMKM makanan ringan di Kaupaten Subang merupakan usaha yang telah turun temurun. Hal ini disebabkan karena masih sempitnya daerah pemasaran untuk produk yang dihasilkan dari pelaku usaha. Termasuk Usaha atau Industri mikro karena melihat dari investasi dan modal yang kecil. Bahwa rata-rata pemilik usaha termasuk kedalam kriteria Usaha Industri Mikro atau industry rumah tangga, memiliki kesadaran hukum khususnya dibidang bisnis atau wirausaha. 


\section{Penilaian Pemilik Usaha Terhadap Orientasi Pasar, Inovasi Produk dan Kinerja Pemasaran}

Sedangkan penilaian pemilik usaha berikut ini:

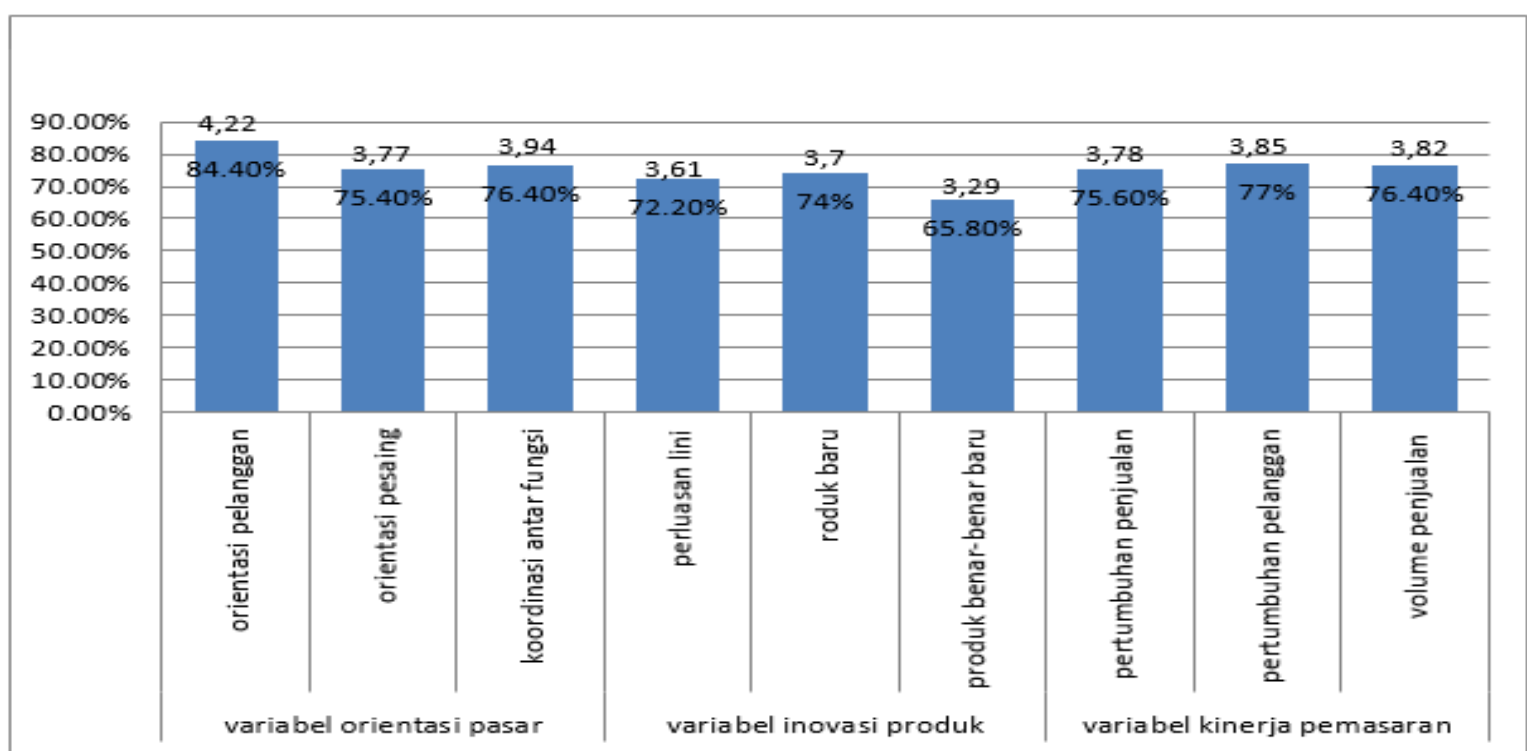

Gambar 2. Rekapitulasi Hasil Penilaian Pemilik Usaha (Sumber : Data diolah, 2019)

Berdasarkan Gambar 2 hasil dari rekapitulasi menyatakan bahwa rata-rata penilaian pemilik usaha terhadap orientasi pelanggan sebesar 84,40 persen, orientasi pesaing 75,40 persen dan koordinasi antar fungsi sebesar 76,40 persen, ketiga indikator pada variabel orientasi pasar tersebut termasuk kategori baik, bahwa orientasi pasar merupakan salah satu hal penting dalam mencapai suatu kinerja pemasaran yang baik. Perusahaan yang berorientasi pada pasar memberikan perhatian seimbang baik untuk konsumen maupun pesaing dalam mendesain strategi pemasarannya (Jaworski dan Kohli 1993). Sedangkan rata-rata rekapitulasi penilaian pemilik usaha pada setiap indikator variabel inovasi produk yaitu indikator perluasan lini sebesar 72,20 persen produk baru 74 persen dan produk benar-benar baru sebesar 65,80 persen, ketiganya memiliki interpretasi baik. Noble dkk (2002) menyatakan bahwa inovasi bagian dari karakter kerja yang menghubungkan budaya perusahaan dengan kemampuan berinovasi untuk meningkatkan kinerjanya. Rekapitulasi penilaian pemilik usaha terhadap pertumbuhan penjualan sebesar 75,60 persen, pertumbuhan pelanggan 77 persen dan volume penjualan sebesar 76,40 persen ketiga indikator pada kinerja pemasaran tersebut termasuk dalam kategori tinggi. Hal ini menunjukan bahwa kinerja pemasaran tidak akan tercapai dan terukur jika perusahaan tidak mempunyai strategi untuk memperoleh kinerja pemasaran yang tinggi. Surya Winata (2010) menyebutkan kinerja pemasaran merupakan elemen penting dari kinerja perusahaan secara umum karena kinerja suatu perusahaan dapat dilihat dari kinerja pemasaran yang telah dilakukan selama ini.

\section{Aspek Lingkungan bagi IMKM}

IMKM makanan ringan limbah yang dihasilkan dari industri mikro kecil dan menengah hampir tidak ada. Limbah padat yang dihasilkan tersebut dapat dimanfaatkan sebagai pupuk atau sebagai pakan ternak. Sedangkan limbah berupa limbah cair proses pencucian dan limbah padat sisa produksi atau kemasan produk dan tidak tergolong kategori B3. Limbah cair hanya disalurkan langsung ke saluran pembuangan, sementara limbah padat dikumpulkan ke tempat 
pembuangan sementara (TPS) untuk selanjutnya diangkut ke tempat pembuangan akhir (TPA). Perubahan lingkungan yang sangat cepat bagi makanan ringan dalam usaha kecil, perlu diantisipasi oleh IMKM secara cepat pula. Antisipasi perubahan lingkungan ini dapat dilakukan dengan berbagai kegiatan seperti pelatihan peningkatan kemampuan mengelola IMKM, mengembangkan inovasi produk dll.

\section{Teknologi Tepat Guna bagi IMKM}

Teknologi tepat guna (TTG) IMKM makanan ringan sesuai dengan kondisi, waktu, ruang, serta mudah dijangkau dan dipahami oleh masyarakat pengguna. Dalam pengembangan teknologi tepat guna ini, membutuhkan dukungan ilmu pengetahuan dan teknologi. Dari bahan baku (seperti mutu bahan baku yang akan diolah), proses produksi yang efisien dan efektif dalam penggunaannya sampai kepada teknologi untuk menangani produk yang dihasilkan (pengemasan produk) sehingga produk yang dihasilkan bisa diterima oleh masyarakat. Penanganan secara fisik diantaranya adalah dengan pemanasan, pembekuan, pengeringan dan pengawetan dengan menggunakan garam, gula dan asam. Sedangkan penanganan secara kimiawi dilakukan dengan penambahan enzim dan bahan-bahan kimia dalam proses pengolahan makanan ringan. Teknologi proses yang digunakan untuk IMKM makanan ringan pada prinsipnya harus memenuhi syarat mudah, murah dan bisa dimodifikasi dalam penggunaannya, sehingga menyarankan penguasaan teknologi yang akan diadopsi.

\section{Modal dan Subyek Pemilik Usaha IMKM}

Berdasarkan modal yang digunakan, industri dengan penanaman modal dalam negeri (PMDN) merupakan industri yang memperoleh dukungan modal dari pemerintah atau pengusaha nasional (dalam negeri). Misalnya: industri kerajinan, industri pariwisata, dan industri makanan dan minuman (makanan ringan). Sedangkan subjek pengelolaannya, termasuk industri rakyat yang dikelola dan merupakan milik rakyat, misalnya: industri meubeler, industri makanan ringan, dan industri kerajinan. Modal IMKM perlu dukungan pemerintah agar akses ke lembaga keuangan dapat cepat diperoleh dengan mudah. Sedangkan subyek pemilik usaha IMKM perlu diperkuat dengan aspek-aspek kewirausahaan sehingga membantu pemilik usahanya

\section{Uji Validitas dan Reliabilitas Instrumen Penelitian}

Validitas suatu ukuran yang menunjukan tingkat kevalidan atau kesahihan suatu instrumen. Berdasarkan pengujian instrumen menunjukan bahwa uji validitas terkait variabel orientasi pasar, inovasi produk dan kinerja pemasaran dikatakan valid karena nilai korelasi yang sesuai dengan nilai ketetapan yaitu $r_{\text {hitung }}>r_{\text {tabel }}(0,30)$, nilai $r_{\text {hitung }}$ semua instrumen $>0,30$, maka dapat dilanjutkan ke pengujian reliabilitas (Sugiyono, 2017). Reliabilitas indikasi mengenai stabilitas dan konsistensi instrument, mengukur konsep dan membantu nilai ketepatan sebuah pengukuran (Sekaran, 2006). Berdasarkan pengujian instrument penelitian menunjukkan bahwa orientasi pasar, inovasi produk, dan kinerja pemasaran diperoleh hasil jika seluruh item reliabel karena memiliki Cronbach Alpha> 0,6.

\section{Uji Asumsi Klasik}

Uji asumsi klasik dengan metode ordinary least square (OLS) dengan uji normalitas, uji multikoliniaritas, uji heterokedastisitas (Ghozali, 2011). Hasil uji yaitu: a) bahwa data dinyatakan terdistribusi normal; b) tidak terjadi multikolonieritas antara variabel bebasnya; c) tidak ada heterokedastisitas dari semua model regresi sehingga semua model regresi dapat dilanjutkan ke uji regresi linear berganda. 
INOBIS: Jurnal Inovasi Bisnis dan Manajemen Indonesia

Volume 02, Nomor 02, Maret 2019

Dwi Gemina, Endang Silaningsih, Karimatun Nisa

\section{Hasil Pengolahan Data}

Analisis data memakai SPSS type 22.0, berikut rangkuman hasil perhitungan:

Tabel 6. Rangkuman Hasil Perhitungan Orientasi Pasar dan Inovasi Produk Terhadap Kinerja Pemasaran IMKM Makanan Ringan di Kabupaten Subang

\begin{tabular}{|c|c|c|c|c|c|}
\hline \multirow{2}{*}{ Model } & \multicolumn{2}{|c|}{ Unstandardized Coefficients } & \multirow{2}{*}{$\begin{array}{c}\text { Standardized } \\
\text { Coefficients } \\
\text { Beta } \\
\end{array}$} & \multirow{2}{*}{$\mathbf{t}$} & \multirow{2}{*}{ Sig. } \\
\hline & B & Std. Error & & & \\
\hline (Constant) & $\overline{5,120}$ & 6,827 & & 0.750 & 0,457 \\
\hline Orientasi Pasar $\left(\mathrm{X}_{1}\right)$ & 0,472 & 0,153 & 0,426 & 3,086 & 0,003 \\
\hline Inovasi Produk $\left(\mathrm{X}_{2}\right)$ & 0,292 & 0,115 & 0,350 & 2,534 & 0,015 \\
\hline $\mathrm{t}$-tabel & $=1,677$ & & & & \\
\hline F-hitung & $=23,603$ & & & & \\
\hline Sig & $=0,000$ & & & & \\
\hline F Tabel & $=3,20$ & & & & \\
\hline $\mathrm{R}$ & $=0,708$ & & & & \\
\hline $\mathrm{R}^{2}$ & $=0,501$ & & & & \\
\hline Adjusted $\mathrm{R}^{2}$ & $=0,480$ & & & & \\
\hline Alpha $(\alpha)$ & $=0,05$ & & & & \\
\hline SEE & $=3,816$ & & & & \\
\hline
\end{tabular}

Sumber: Data Diolah, 2019

Berdasarkan tabel rangkuman hasil perhitungan statistik diperoleh nilai $\mathrm{R}$ atau korelasi sebesar 0,708, yang menunjukan bahwa angka korelasi 0,708 berada pada kategori kuat, sehingga orientasi pasar dan inovasi produk dengan kinerja pemasaran memiliki hubungan yang kuat. Artinya bahwa semakin tinggi orientasi pasar dan inovasi produk maka kinerja pemasaran akan semakin meningkat, sedangkan nilai $R$ Square yang diperoleh sebesar 0,501 atau $50,1 \%$. Bahwa presentase sumbangan pengaruh variabel faktor orientasi pasar dan inovasi produk terhadap kinerja pemasaran sebesar 50,1 persen. Sedangkan sisanya sebesar $49,9 \%$ dipengaruhi oleh faktor lain yang tidak termasuk model penelitian ini seperti kelengkapan produk dan efektifitas saluran distribusi (Depary, 2010). Didukung dengan hasil koefisien determinasi dari penelitian Wulandari (2012) yang menunjukan kontribusi dari orientasi pelanggan, orientasi pesaing dan inovasi produk terhadap kinerja pemasaran sebesar 53,1 persen.

\section{Pengaruh Orintasi Pasar dan Inovasi Produk Secara Simultan Terhadap Kinerja Pemasaran}

Hasil uji simultan dengan nilai $F_{\text {hitung }}$ sebesar 23,603 dan nilai $F_{\text {tabel }}$ untuk $\alpha=0,05$ sebesar 3,20. Bahwa $F_{\text {hitung }}$ lebih besar dari $F_{\text {tabel }}(23,60>3,20)$ bahwa $\mathrm{H}_{0}$ ditolak dan $\mathrm{H}_{\mathrm{a}}$ diterima, artinya dengan tingkat kepercayaan 95 persen variabel orientasi pasar dan inovasi produk berpengaruh positif dan signifikan secara simultan (bersama-sama) terhadap Kinerja pemasaran IMKM makanan ringan Kabupaten Subang. Oleh sebab itu kinerja pemasaran merupakan konsep untuk mengukur prestasi pemasaran suatu perusahaan (Surya Winata, 2010). Hal ini di dukung oleh hasil penelitian Lapian dkk (2016) menyatakan bahwa variabel orientasi pasar dan inovasi produk secara bersama-sama berpengaruh positif dan signifikan terhadap kinerja pemasaran. 


\section{Pengaruh Orintasi Pasar Terhadap Kinerja Pemasaran}

Hasil uji parsial dengan nilai thitung pada variabel orientasi pasar sebesar 3,086 dan nilai $t_{\text {tabel }}$ untuk $\alpha=0,05$ sebesar 1,677 berarti $t_{\text {hitung }}>t_{\text {tabel }}(3,086>1,677)$. Hal ini dapat dilihat dari nilai koefisien korelasi 0,472 serta memiliki nilai signifikansi sebesar $0,003<0,05$. Maka dengan demikian $\mathrm{H}_{\alpha}$ diterima dan $\mathrm{H}_{0}$ ditolak, artinya faktor orientasi pasar berpengaruh positif dan signifikan terhadap kinerja pemasaran IMKM makanan ringan Kabupaten Subang. Hal ini di dukung oleh hasil penelitian Putro (2018) menyatakan bahwa secara parsial orientasi pasar berpengaruh yang positif dan signifikan terhadap kinerja pemasaran.

\section{Pengaruh Inovasi Produk Terhadap Kinerja Pemasaran}

Nilai $t_{\text {hitung }}$ pada variabel inovasi produk sebesar 2,543 dan nilai $t_{\text {tabel }}$ untuk $\alpha=0,05$ sebesar 1,677 berarti $t_{\text {hitung }}>t_{\text {tabel }}(2,543>1,677)$. Hal ini dapat dilihat dari nilai koefisien regresi 0,292 serta memiliki nilai signifikansi sebesar 0,015<0,05. Maka dengan demikian $\mathrm{H}_{\alpha}$ diterima dan $\mathrm{H}_{0}$ ditolak, artinya faktor inovasi produk berpengaruh positif dan signifikan terhadap kinerja pemasaran IMKM makanan ringan Kabupaten Subang. Menurut Hubeis (2012) menyatakan bahwa inovasi produk merupakan pengetahuan produk baru yang seringkali di kombinasikan dengan hal baru untuk membentuk metode produksi yang tidak diketahui. Hal ini di dukung oleh hasil penelitian Dwiyono (2006) bahwa semakin tinggi inovasi produk maka semakin tinggi pula kinerja pemasaran.

\section{Kesimpulan}

Adapun simpulan bahwa:

1) Rata-rata tanggapan pemilik usaha terhadap orientasi pasar dengan interpretasi baik, rata-rata tanggapan pemilik usahaterhadap inovasi produk dengan interpretasi baik, rata-rata tanggapan pemilik usaha terhadap kinerja pemasaran dengan interpretasi tinggi. Hubungan antara kinerja pemasaran dan orientasi pasar serta inovasi produk dinyatakan kuat karena hasil pada pengujian korelasi menunjukan nilai sebesar 0,708 , sedangkan berdasarkan hasil pengujian koefisien determinasi orientasi pasar dan inovasi produk memiliki pengaruh sebesar 0,501 atau $50,1 \%$, sedangkan $49,9 \%$ sisanya di pengaruhi oleh faktor lain yang tidak diteliti;

2) Orientasi pasar dan inovasi produk secara simultan berpengaruh positif dan signifikan terhadap kinerja pemasaran IMKM makanan ringan di Kabupaten Subang; 3) Orientasi pasar dan inovasi produk secara parsial berpengaruh positif dan signifikan terhadap kinerja pemasaran IMKM makanan ringan di Kabupaten Subang.

Implikasi secara teoritis pada penelitian ini adalah kinerja pemasaran berbasis orientasi pasar dan inovasi produk yang dimiliki pemilik usaha IMKM makanan ringan hendaknya dipertahankan dan ditingkatkan kuantitas maupun kualitasnya sehingga sesuai dengan harapan pemilik usaha IMKM. Hasil penelitian ini diharapkan dapat memperkuat pengembangan ilmu khususnya dibidang manajemen terutama kajian pemasaran pada IMKM. Untuk menunjang pembangunan dan pengembangan ilmu pengetahuan dan teknologi dalam rangka memperkuat daya saing, pembangunan sektor perdagangan dan kewirausahaan perlu diarahkan untuk menciptakan sistem perdagangan dalam negeri yang kuat dan efisien yang mampu meningkatkan daya saing produk unggulan daerah atau produk nasional yang berkualitas melalui pemasaran. 
Keterbasan penelitian ini hanya menggunakan sampel relative sedikit (50 responden) yang berasal dari Kabupaten Subang sehingga hasilnya belum optimal dan penelitian kedepan dapat diarahkan pada kelengkapan produk dan efektifitas saluran distribusi dengan harapan dapat diperoleh hasil yang lebih sempurna.

\section{Daftar Pustaka}

Arikunto, Suharsimi. (2011). Prosedur Penelitian: Suatu Pendekatan Praktek. Jakarta: Rineka Cipta.

Akbar, S.P dan H. Usman. (2006). Metode Penelitian Sosial. Jakarta: Bumi Aksara.

Ahmad Yahya Surya Winata. (2010). Mengukur Kinerja Pemasaran: Kajian Konseptual

Perkembangan Teori. Jurnal Riset Akuntansi dan Bisnis. Vol 10 No. 2 . Hal 194-

219.

Badan Pusat Statistik Kabupaten Subang. (2019). Kabupaten Subang dalam Angka.

Charles, Noble H. Sinha, Rajiv K. and Kumar, Ajith. (2002). Market Orientation and

Alternative Strategic Orientations : A Longitudinal Assessment of Performance

Implications, Journal of Marketing Vol. 66, Hal. 25-39.

Dinas Koperasi Perindustrian dan Perdagangan (Diskoperindag). (2019). Klasifikasi

Data Industri Kecil dan Menengah Makanan Ringan Kabupaten Subang.

Dinas Koperasi Perindustrian dan Perdagangan. (2018). Daftar Industri Mikro Kecil dan Menengah Makanan Ringan Kabupaten Subang.

Depary, Astrid Orsini. (2010). Analisis Fakto-faktor Yang Mempengaruhi Kinerja Pemasaran. Semarang. Tesis. UNDIP. https://undip.ac.id di akses pada 20 Desember 2019 pukul 10:30 WIB.

Dwiyono. (2006). Studi Mengenai Inovasi Produk dan Kinerja Pemasaran (Studi

Empiris pada Industri Mebel Ekspor Skala Sedang dan Besar di Jepara). Jurnal

Sains Pemasaran Indonesia. Vol.V No.3. Hal. 269-286.

Ferdinand, Augusty. (2006). Metode Penelitian Manajemen. Semarang: BP Undip.

Gay, L.R. and Diehl, P.L. (1992). Research Methods for Business and Management. New York: Mc. Millan Publishing Company.

Ghozali, Imam. (2011). Aplikasi Analisis Multivariate Dengan Program APSS. Semarang. Badan Penerbit Universitas Diponegoro.

Han, Jin K. Namwoon Kim. \& Rajendra K. Srivastava. (1998). Market Orientation and Organizational Performance : Is Innovation a Missing Link?. Journal of Marketing. Vol. 02. Hal. 30-45.

Hubeis, Musa. (2012). Manajemen Kreativitas dan Inovasi dalam Bisnis. Jakarta: Penerbit PT. Hecca Mitra Utama.

Jaworski dan Kohli. (1993). Market Orientation: Antecedents and Consequences. Journal of Marketing. Vol. 57 No. 3. Hal. 53-71.

Lapian, Adelia Agnes, James Massie, Imelda Ogi. (2016). Pengaruh Orientasi Pasar dan Inovasi Produk terhadap Kinerja Pemasaran pada PT. BPR Prisma Dana Amurang. Jurnal EMBA. Vol.4. No.1 Maret 2016. Hal 1330-1339.

Lukas, B.A. and Ferrel, O.C. (2000). The Effect of Market Orientation on Product Innovation. Journal of The Academy Marketing Science. No.2 Vol.28. Hal.239-247

Mashuri. (2008). Penelitian Verifikatif. Edisi Pertama.Yogyakarta: Andi.

Mulyani, Ida Tri. (2015). Upaya Meningkatkan Kinerja Pemasaran Melalui Orientasi Pasar dan Orientasi Kewirausahaan dengan Inovasi sebagai Variabel Intervening (Studi Empiris pada Usaha Mikro Kecil dan Menengah Kota Semarang). Diponegoro Journal of Management. Vol.4. No.3. Hal 1-12. 
Narver, John. C., and Stanley F. Slater. (1990). The Effect of a Market Orientation on Business Profitability. Journal of Marketing.Vol.24. No.88 Hal. 20-35.

Prajogo D.I, A.S. Sohal. (2006). The Relationship Between Organization Strategy,Total Quality Management (TQM), and Organization Performance-the Mediating Role of TQM. European Journal of Operational Research. Vol. 25. No. 11. Hal. 82-105.

Permadi, MF. (2000). Pengembangan Konsep Kinerja Pasar. Jurnal Ekonomi dan Bisnis Indonesia. Vol.13, No.3. Hal. 10-23

Putro, Aris Styo. (2018). Analisis Pengaruh Orientasi Pasar dan Inovasi Produk untuk Meningkatkan Kinerja Pemasaran pada Kampung Batik Laweyan Solo. Surakarta. Skripsi. IAIN Surakarta. https://iain.ac.id di akses pada 20 Desember 2019 pukul 11:30 WIB

Saiman, L. (2013). Kewirausahaan. Teori Praktik Dan Kasus-Kasus. Jakarta: Salemba Empat.

Surya Winata, Ahmad Yahya. (2010). Pengukuran Kinerja Pemasaran: Kajian Konseptual Perkembangan Teori. Jurnal Riset Akuntansi dan Bisnis. Vol 10. No. 2. Hal. 149 219.

Suryana, Yuyus dan Kartib Bayu. (2010). Kewirausahaan (Pendekatan Karakteristik Wirausahawan Sukses. Jakarta: Prenada Media Group.

Sulus. Fahmi. (2017). Pengaruh Orientasi Pasar dan Inovasi Produk terhadap Kinerja Pemasaran (Studi pada Industri Rotan Kecil dan Menengah di Desa Trangsan Kecamatan Gatak Kabupaten Sukoharjo.IAIN Surakarta. Skripsi. Fakultas Ekonomi dan Bisnis Islam.https://iain.ac.id di akses pada 21 Desember 2019 pukul 11:30 WIB.

Supardi. (2013).Aplikasi Statistika dalam Penelitian Konsep Statistika yang Lebih Komprehensif. Jakarta:Change Publication.

Sugiyono. (2017). Metode Penelitian Kuantitatif, Kualitatif dan R \& D. Bandung: Alfabeta.

Sekaran, Uma. (2006). Metodologi Penelitian untuk Bisnis. Edisi 4. Buku 2. Jakarta: Salemba Empat.

Tambunan, T. (2012). Usaha Mikro Kecil Dan Menengah di Indonesia (Isu-Isu Penting). Jakarta: LP3S.

Tanjung, M.Azrul. (2017). Koperasi dan UMKM sebagai Fondasi Perekonomian Indonesia. Jakarta: Erlangga.

Tjiptono, Fandy dan Gregorius Chandra. (2012). Pemasaran Strategik. Yogyakarta: Andi.

Tjiptono, Fandy. (2008). Pemasaran Strategik.Yogyakarta: Andi Offset.

Undang-Undang No.13 tentang Ketenagakerjaan.

Uncles, Mark. (2000). Market Orientation. Australian Journal of Management. Vol.25, No.2. Hal. 1-15.

Wulandari, Agesti. (2012). Pengaruh Orientasi Pelanggan, Orientasi Pesaing dan Inovasi Produk terhadap Kinerja Pemasaran. Management Analisys Journal. Vol.2 No.1. Hal $18-27$.

Zulkarnaen, Oky Halim. (2013). Analisis Strategi Pemasaran pada Usaha Kecil Menengah (UKM) Makanan Ringan. Semarang. Skripsi diterbitkan UNDIP. https://undip.ac.id di akses pada 20 Desember 2019 pukul 12:30 WIB 